\title{
Agencies to mitigate space station delays
}

[WASHINGTON \& MUNICH] Life scientists and microgravity researchers face serious delays to the start of their experiments on the international space station as a result of proposed changes to its construction schedule being discussed this week in Moscow.

If US and Russian negotiators agree on a plan to shift part of the burden for supplying the station from Russian to US space vehicles, the need for extra space-shuttle missions could delay the seven scientific 'utilization' flights planned between 2000 and 2003 . These would furnish the laboratory with experiment 'racks' that can be used for a variety of investigations.

Although the new assembly schedule has not been finalized, the average delay for utilization flights would probably be about six months, according to Mark Uhran of the US space agency NASA's Office of Life and Microgravity Sciences. Construction of the station starts next month, with the first utilization flight planned for April 2000.

The proposed schedule changes - made necessary by Russia's inability to pay for key elements it had promised to deliver - could also delay the completion of the station, now planned for 2004, by up to a year. Because the

laboratory module of the European Space Agency (ESA) is among the last elements to be attached, European use of the station would probablybe affected.

US space managers have been struggling for months to find a politically acceptable solution to the Russian problem, which threatens the project's schedule, if not its very survival. NASA now hopes to pay Russia $\$ 60$ million immediately to finish work on a crucial 'service module' scheduled for launch next summer as the station's centrepiece during its early stages of assembly.

But a more ambitious NASA plan to buy an extra $\$ 600$ million worth of Russian hardware and services over the next four years got a chilly reception last week from key figures in the US Congress. These included House Science Committee chairman James Sensenbrenner (Republican, Wisconsin), Senate Science Committee chairman John McCain (Republican, Arizona) and House Speaker Newt Gingrich (Republican, Georgia), who called the current US-Russian agreement on the station an "absolute disaster".

With further slip in the schedule now almost inevitable, NASA hopes to soften the blow for space researchers by accommodating

\section{Japan looking forward to Christmas Island}

[TOKYO] Japan's National Space Development Agency (NASDA) is to build a new space centre on Kiritimati, formerly Christmas Island, in the South Pacific, part of the Republic of Kiribati.

Programmes to be carried out there will include the development and launch of the unmanned experimental space vehicle HOPE-X, designed to ferry equipment to and from the experimental space station.

NASDA is negotiating with the Kiribati government for a 20-year lease on the southeastern part of the island. It plans to build a space port to carry out some activities transferred from its main space centre in Tanegashima, an island off Japan's south coast. These would be Japan's first space operations on foreign soil.

The Tanegashima Space Centre is shifting towards launching commercial satellites, leaving the planned space centre in Kiritimati to be at the heart of Japan's space development programmes.

Some scientists are concerned that Japan's participation in the international commercial satellite business, scheduled to begin in 2000, will affect NASDA's research activities.

Rocket System, a Japanese company that launches commercial satellelites, has signed a contract with Hughes Space and Communication

International and Space Systems/Loral to launch more than 20 satellites from Tanegashima between 2000 and 2007 (see Nature 392 321; 1998).

NASDA initially considered building the new centre on one of the islands in Japanese territory, but Kiritimati, near the equator, was geographically, climatically and politically more favourable. It was used for nuclear experiments by Britain and the United States between 1956 and 1963, so
NASDA is likely to face a major task in clearing up the debris that has been left behind.

There were political problems associated with most of the locations in Japan, says a NASDA spokesman, as test-flying HOPE-X would have risked entering Chinese and Korean airspace.

HOPE-X, a joint project between NASDA and the National Aerospace

Laboratory, is an experimental vehicle to establish the technologies needed for the recovery and supply of equipment from the international space station.

NASDA also hopes to carry out research and development of HOPE, a space shuttle for practical missions and next-generation launch vehicles, at the planned space centre, indicating that a significant part of NASDA's R\&D might be transferred to the South Pacific island. Asako Saegusa

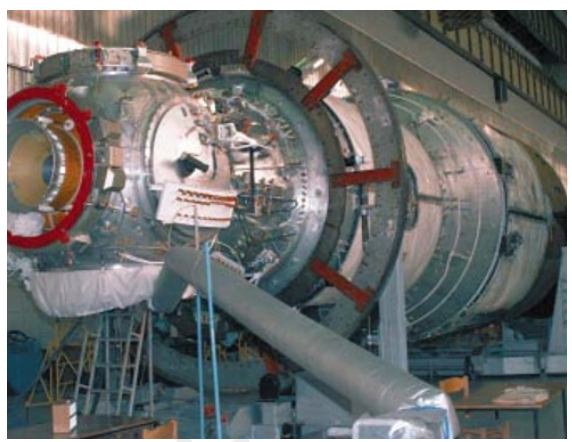

Critical component: the Russian service module under construction at Khrunichev space centre.

more experiments on the proposed halfdozen extra space-shuttle resupply flights.

Another possibility is for NASA to use the Russian service module, which is nearly identical to the Mir station that housed several US experiments over the past three years. But the research community would be limited by scarce funds to flying mostly repeats of past experiments, according to Uhran.

ESA, meanwhile, wants to help its small space research community weather the delay by starting up a granting programme for ground-based experiments in life-sciences space research. The proposed scheme, suggested as part of ESA's programme for exploitation of the space station from 2000 to 2004, was discussed this week by ESA's Microgravity Programme Board, which includes representatives from ESA member states.

The scheme would give researchers access to large-scale facilities such as those designed to model aspects of living in space, including bed-rest, confinement and isolation facilities, and would help them build up facilities in their own institutes.

To complement the scheme, ESA is trying to persuade the European Commission to include ground-based space biology in its fifth Framework programme (FP5), which is due to begin operation next year, to provide researchers with project money.

"More ground-based work will allow experiments to be very carefully designed on the ground, so that we can be sure they will work in space," says Didier Schmitt, director of ESA's life sciences department.

The proposed 2000-2004 space-station exploitation programme continues microgravity work in life sciences in parallel to ground-based work, which includes sounding rocket experiments and parabolic flights.

ESA has also negotiated space for some experiments on the privately owned Spacehab, which will fly in the space shuttle's cargo bay later this month and again in 2000. "We hope the space station is not delayed", says Didier. "But if it is we hope to have a complete strategy to keep our scientific community going.” Tony Reichhardt \& Alison Abbott 